\title{
EDITORIAL COMMUNICATIDN
}

The Review of Politics, which with this issue begins its forty-sixth year of publication, is pleased to announce the formation of a board of outside advisory editors, the first in the journal's history. Consisting of thirteen prominent scholars whose names appear on the inside cover, the new board will be consulted regularly on the progress and quality of THE Review. The organization of an advisory board also coincides with the appointment of a new editorial team, including three associate editors and a book review editor. The moment is thus a timely one to say a word about THE Review's publishing policies.

Since its founding THE REviEw has described itself as being "primarily interested in the philosophical and historical approach to political realities." The Editors continue to adhere to this general statement of purpose. One of the elements of THE REviEw's broad appeal-and success-over the decades, in Europe as well as in the United States, has been its firm footing in the humanities and its role in serving as a bridge between disciplines concerned with the political life of persons and communities. By the same token, THE Review's pages have been particularly receptive to men and women of broad culture and learning who have had something significant to say about the political condition of the human species. THE REviEW is not therefore an exclusively professional or specialist journal. Yet it is the product of professional scholarship, and politics is clearly its specialty.

THE REviEw's interest is accordingly confined to scholarly articles. Such articles should combine accurate research, literary merit, and broad appeal. They should build on previous knowledge, advance understanding of politics, and stimulate further research or disciplined inquiry. Although favoring the historical and philosophical approach to politics, THE REVIEW accepts technical and institutional studies so long as they appeal to a general readership, are clearly written, and make equally clear their broader theoretical or applied significance. With these standards in mind THE Review does not ordinarily accept notes on research methodology, routine summaries of books or scholarly arguments, descriptive accounts of minor figures, public speeches, or general commentaries on public events.

THE Review continues, as before, to be keenly interested in the exploration of political ideas and in the critical examination of modern politics through the prism of the Judaeo-Christian and 
other philosophical traditions. International relations and diplomacy and comparative politics also remain high on its list of priorities. THE REVIEW is particularly receptive to articles dealing with the relations between the developed and underdeveloped nations of the world, and to the emerging problems of postindustrial societies and modern constitutional democracies. Finally, THE REview hopes to publish more in the field of American politics. Particularly welcome are manuscripts focusing on civil and human rights, constitutional theory, church-state relations, and the priorities of national policy.

A note on the handling of manuscripts should be added. Although THE Review is a publication of the University of Notre Dame, ninety-nine percent of all manuscripts received by THE REVIEW originate outside of its patron university. THE REviEw does not solicit manuscripts; it depends on voluntary submissions. When a manuscript arrives it is read internally by two editors. If it does not satisfy certain threshold requirements of literary style and analysis it is returned to the author within five weeks; if this requirement is satisfied, it is then sent anonymously to at least two outside referees who are specialists in the subjectarea concerned. Manuscripts are internally assessed largely on the basis of referee reports, and THE REVIEW makes a serious effort to finish the process of evaluation in three months. Most manuscripts accepted by THE REviEw are in need of revision. Once a manuscript is finally accepted, however, publication usually takes place within a year.

Other aspects of THE REvIEW deserving of mention are the book review section and a new communications section. Owing to its limited space THE Review publishes on the average six to ten book reviews per issue, but these are usually longer than those appearing in the ordinary academic journal. It prefers reviews that are analytical and evaluative rather than simply descriptive, marked by distinct literary merit, and related to its substantive concerns. THE Review is partial to the academic press and has a tendency to review books not likely to receive much popular notice. Books and reviewers are accordingly selected with considerable care. Recently the editors decided to accept letters or communications about published articles. Such letters, however, will be published at the discretion of the editors and only when such exchanges help to advance understanding of the issue under consideration. 